\title{
Teachers' Use of Scaffolding Strategies During Read Alouds in the Preschool Classroom
}

\author{
Jill M. Pentimonti • Laura M. Justice
}

Published online: 8 October 2009

(C) Springer Science+Business Media, LLC 2009

\begin{abstract}
Relatively little is known regarding preschool teachers' use of specific scaffolds, including those high support scaffolds (e.g., co-participating, eliciting, reducing choices) that may be important for children who are struggling to acquire language and literacy concepts. The goal of this study was to characterize preschool teachers' use of six types of scaffolds (generalizing, reasoning, predicting, co-participating, reducing choices, eliciting; see O'Connor et al. in Ladders to literacy, Paul H. Brookes Publishing, Baltimore, MD, 2005) within the whole group read aloud session. Two specific questions were addressed: (1) To what extent do preschool teachers use high and low support scaffolds during whole group read aloud sessions? and (2) To what extent does preschool teachers' perceived frequency of use of specific scaffolds correspond to their actual use of scaffolds? Videotaped classroom observations were carried out for five preschool teachers conducting whole group read alouds in their classrooms; frequency of use for six types of scaffolds was coded using systematic observation procedures. Results indicated that teachers showed a preference for three types of scaffolds, all of which were low support, and that the three types of high support scaffolds occurred at very low rates. Additionally, results showed a substantial discrepancy between teachers' perceived frequency of use of specific types of scaffolds relative to their actual use. Together, findings suggest that preschool teachers may benefit from professional development focused on using a range of scaffolds, to include
\end{abstract}

J. M. Pentimonti $(\square) \cdot$ L. M. Justice

College of Education and Human Ecology, The Ohio State

University, 356 Arps Hall, 1945 N. High St., Columbus, OH

43210, USA

e-mail: JPentimonti@ehe.osu.edu high support scaffolds beneficial to children who may need high levels of support to participate in read alouds.

Keywords Scaffolding - Read aloud P Preschool . Emergent literacy

\section{Introduction}

Literacy development is a complex process that begins prior to the advent of formal reading instruction. The skills and knowledge acquired as precursors to reading and writing are often referred to as emergent literacy (Whitehurst and Lonigan 1998). Young children's participation in read aloud activities is viewed as a particularly important context for facilitating their development of key emergent literacy skills, including vocabulary knowledge and print awareness (Bus 2001; Justice and Ezell 2002; Senechal and Cornell 1993; Senechal 1997). Given that many children today participate in preschool programs, and read alouds are a regular occurrence in many of these settings (Dickinson et al. 1992), it is important to understand read aloud processes specific to the preschool classroom. In particular, there is a need to study how preschool teachers use various strategies, or scaffolds, to support children's development of emergent literacy skills within the read aloud context. Teachers' use of scaffolds refers to the process of temporarily providing support to a learner and then gradually withdrawing this support as the learner becomes capable of independence in performing tasks (Wood et al. 1976). Although specific types of scaffolds have been identified as particularly useful for developing children's emergent literacy skills, such as predicting and reasoning (van Kleeck et al. 2006), little research has studied how preschool teachers use these in the naturalistic context of their 
classrooms. To contribute to this literature, this study determined (a) the frequency with which preschool teachers used six specific types of scaffolding strategies during read alouds in their classrooms (generalizing, reasoning, predicting, co-participation, reducing choices, eliciting), and (b) the extent to which preschool teachers adequately self-calibrated their use of these six strategies. Therefore, in the following brief overview of the literature, key topics to be addressed are; (a) the read aloud context, (b) scaffolding and (c) types of scaffolding.

\section{The Read Aloud Context}

A number of studies have shown that read aloud experiences are particularly influential to young children's development of important emergent literacy skills (Price et al. 2009; Justice and Ezell 2002; van Kleeck et al. 2006). Descriptive and experimental studies of read-aloud interactions provide clues as to why this activity may be so beneficial to young children's development (Price et al. 2009; Justice and Ezell 2002; Lynch and van den Broek 2007; Senechal and Cornell 1993). These benefits are influenced by factors such as the social context created between adult and child and the quality of conversation embedded within the read aloud experience (Dickinson and Tabors 2001; Neuman 1996; Sulzby and Teale 1996).

With respect to social context, read alouds are a highly socialized activity, therefore providing an interactive context within which children learn and apply verbal and conceptual skills (Neuman 1996). Read alouds are also a highly predictable and routinized activity, providing a systematic format that helps young children learn how to participate in literacy events (Sulzby and Teale 1996). Additionally, exposure to various texts through read aloud interactions may help to prepare children for future social interactions involving literacy. In a seminal work on this topic, Heath (1983) pointed to similarities between adults reading traditional storybooks to young children and the literacy events children experience later in formal schooling.

A particularly interesting aspect of the read-aloud context, and one that is relevant to this study, concerns the types of conversations that take place as adults share books with children. Through participation in extra-textual conversations that supplement the adult's reading of the text itself, young children learn to talk about words, stories, and characters, and answer questions about these features of the text through the joint read-aloud interaction (Pellegrini and Galda 2003). Reading aloud provides a context through which adults and children share a joint topic focus, which affords an opportunity for children to participate in increasingly sophisticated conversations that move beyond a perceptual focus to encompass conceptually oriented discussions (Dickinson and Tabors 2001). Studies have shown that while reading together, adults often ask children to reflect upon the language and conventions used in the texts (Pellegrini et al. 1990). Children can, in turn, use what they have learned about language in other contexts, such as pretend play with peers and more realistic discourse with peers and adults (Pellegrini and Galda 1991).

The conceptually oriented discussions that occur while reading aloud with young children can provide an important context for explicitly facilitating children's skills in specific areas of early literacy, to include vocabulary knowledge, awareness of print, and language comprehension (see Snow et al. 1998; Teale 2003). Experimental evidence provides particularly strong support to this argument. For instance, research findings have shown that children's participation in read alouds that feature strategies such as active engagement through questioning and repeated readings can have positive effects on young children's vocabulary growth (Senechal and Cornell 1993; Senechal 1997; Walsh and Blewitt 2006). Similarly, adult use of a read aloud style that includes questions and comments with an explicit print focus can increase children's knowledge about the nature of written language (Justice and Ezell 2002). In looking at language comprehension, studies show that engaging children in retelling activities during read alouds and rereading texts can have positive impacts on children's comprehension skills (Karweit 1989; Morrow 1988). Additionally, effective instruction relating to comprehension of story structure can occur through read alouds and corresponding activities that highlight story elements (Baumann and Bergeron 1993; Lynch and van den Broek 2007).

\section{Scaffolding}

Within preschool classrooms today, the skills and competencies children exhibit with respect to emergent literacy can vary considerably. Within a given classroom serving 4-year-old children, for instance, some children may not know the letters of the alphabet whereas others may know every letter; similarly, some children may know very few concepts about print (e.g., alphabet knowledge, directionality of print, concept of word) whereas others may know a great deal (Justice and Ezell 2001). At least in part, these individual differences among children reflect the heterogeneity of their home literacy environments (Sénéchal et al. 1998). For instance, children who are reared in homes characterized by limited resources due to low socioeconomic status tend to exhibit less knowledge about the alphabet and print concepts compared to children reared in home of relative advantage (Bowey 1995; Christian et al. 1998; Dodd and Carr 2003; Snow et al. 1998). These children may tend to know less about concepts of print as a result of several factors (e.g., limited amount of print related resources available, lack of transportation to visit a 
library). Importantly, children's experiences within their preschool classrooms can serve to reduce individual differences among children with respect to their emergent literacy skills, and in this regard can help children from low-income homes develop skills that will promote their long-term reading achievement (see National Early Literacy Panel 2008). In fact, recent research findings show that children who attend preschool classrooms characterized by high quality instructional support exhibit greater growth in emergent literacy skill relative to children attending classrooms characterized by low quality instructional support (Mashburn et al. 2009).

Although a number of studies have analyzed features of instruction within the preschool classroom that are associated with children's short- and long-term literacy achievement (Dickinson and Smith 1994; Huttenlocher et al. 2002; Justice et al. 2008; Mashburn et al. 2009; Pence et al. 2008), very few studies have focused specifically on preschool teachers' use of scaffolding strategies.

The term scaffolding is used here to describe the process through which one provides support to learners so as to enable them to complete a task or activity that is beyond their independent capabilities. The notion of scaffolding is situated within Vygotsky's theory of instruction that emphasizes the importance of delivering instruction that is in advance of a child's current level of skill (Vygotsky 1978). According to Vygotsky (1978), instruction should help children develop skills that they have not yet mastered; consequently, instruction provided by teachers will precede children's development of skills required to complete specific tasks.

The scaffolding metaphor is particularly influenced by Vygotsky's idea of the zone of proximal development (ZPD). According to Vygotsky (1978), a child's ZPD is the difference between a child's actual and potential abilities. Children's actual ability corresponds with tasks they can perform independently, while their potential ability corresponds with those tasks that require adult assistance for their completion. In terms of scaffolding, the task given to a child must be at the appropriate level within the child's ZPD for the scaffolding experience to be successful and foster development (Olswang et al. 1992; Pressley et al. 1996). Of relevance to this study is recognizing that this level is unique for each child, a function of context and task, and is constantly changing (Bodrova and Leong 2007; Pressley et al. 1996). That is, for scaffolding to be effective; the teacher (or other adult) gradually withdraws support provided to a learner as he or she becomes more independent in performing specific tasks (Wood et al. 1976). As applied to the classroom context, this means that a teacher instructing a large group of children may simultaneously need to use a diverse range of scaffolding strategies to meet the unique needs of all children in the group.
Types of Scaffolding

Scaffolding strategies can generally be thought of as spanning a continuum of low to high support strategies, which serves to differentiate the amount of support the adult provides to the child while engaged in a given task. Low levels of support featuring minimal levels of adult assistance are those scaffolding strategies provided when a child is nearing maturation in a given area of development or skill; these include such strategies as generalizing, reasoning, and predicting (O'Connor et al. 2005). High levels of support are those strategies featuring more structured adult assistance, typically provided when a child is only beginning to display a skill and requires a great deal of support to complete a task (Norris and Hoffman 1990). These include, for instance, eliciting, reducing choices, and co-participating.

Research on teachers' use of scaffolding strategies in the classroom suggests that they contribute to increased learning and positive outcomes in young children (Henderson et al. 2002; Rodgers 2005). For instance, teachers' use of scaffolding strategies in teacher/student interactions was found to be a strong and positive predictor of young children's scores on standardized measures of intelligence (Roberts and Barnes 1992). However, research has also revealed the complexities involved in teachers' roles in the scaffolding experience. Effective scaffolding interactions require teachers to have a theory of the task and a theory of the student; therefore they must clearly understand the level of scaffolding necessary to assist a student in successfully completing a task. Successful scaffolding requires that teachers have a solid knowledge of curriculum in general and their students' individual needs (Pressley et al. 1996). They also must choose which task most requires instruction and then decide what level of help to provide (Wood et al. 1976). Moreover, the amount and type of support is adjusted as the child assumes more responsibility for learning (Rogoff 1990; Tharp and Gallimore 1988). Effective scaffolding is thought to be responsive to the child, flexible and utilize a variety of strategies (Berk and Winsler 1999). The complexities involved in scaffolding may contribute to research findings showing that teachers in the primary grades do not often engage in use of scaffolding strategies (e.g., Cazden 1988). While it is unclear whether preschool teachers use scaffolding strategies when providing language and literacy instruction in their classrooms, research involving primarygrade teachers suggests that teachers may seldom employ strategies known to positively influence language and literacy development among young children (Pence et al. 2008). 
Importance of the Study

In this study, we determined how often preschool teachers used six specific types of scaffolding strategies viewed as important means for differentiating instruction in large- and small-group activities in preschool classrooms (O'Connor et al. 2005). This work is particularly timely given that the majority of 3- to 5-year old children in the United States attend center-based publicly funded preschools (National Center for Education Statistics (NCES) 2008). Instruction in these preschool programs is guided by learning standards that emphasize a range of language and literacy goals (Neuman and Roskos 2005), and teacher use of read alouds is advocated as an important means to achieving language and literacy learning goals (van Kleeck 2003; Whitehurst and Lonigan 1998) as well as by federal and state level initiatives (e.g. United States Department of Health \& Human Services, Administration for Children \& Families, Office of Head Start 2000; Ohio Department of Education 2008). However, the quality of the read aloud experience, including teacher use of scaffolding strategies when reading, may strongly influence the benefits children derive from these interactions (Scarborough and Dobrich 1994). To understand whether preschool teachers employ various scaffolding strategies during read aloud activities in their classrooms, this study was conducted. To assess teachers' use of various scaffolding strategies, we used both direct assessment (i.e., observation to determine actual rate of use for six types of strategies) as well as indirect assessment (i.e., questionnaire to determine reported rate of use by teachers). By combining both methodologies, we were also able to determine whether preschool teachers reliably calibrated their own rate of use for specific scaffolding strategies, as it is possible that teachers do not accurately represent (i.e., miscalibrate) whether and how often they use various instructional strategies (Cunningham et al. 2004).

\section{Methods}

Participants

Five teachers, all of whom were enrolled in a larger study of preschool classroom instruction, served as participants in this study. The five teachers worked in Head Start classrooms in a rural region of a Midwestern state. The five teachers in the study were all Caucasian females. Four of the teachers held a 2 year Associate's degree whereas the fifth teacher had a Bachelor's degree. Teachers' experience in a preschool setting ranged from nine to 17 years. 18 children were enrolled in four of the classrooms and 17 children were enrolled in one classroom. The average age of participating children was 4 years, 10 months
( $\mathrm{SD}=1$ month). According to parent report, a majority $(58 \%)$ of children's families had annual incomes of less than $\$ 20,000$.

\section{Procedures}

Head Start preschool programs within school districts were recruited to participate in the larger study, subsequent to which preschool teachers agreed to participate at the invitation of their district. Teacher participation spanned an entire academic year (2008-2009). At the start of the study, teachers participated in a 1-day training workshop that included explanation of study procedures as well as various ways to use books in the classroom. Teachers were given guidance in ways to foster learning during read aloud interactions in terms of language and literacy domains. Teachers were also given suggestions for using scaffolding strategies during these read aloud interactions. More specifically, the day-long training included a $2 \mathrm{~h}$ module that discussed the six scaffolding strategies assessed in this study and their use in the classroom. Teachers were provided with definitions and examples of high and low support strategies, adapted from the Ladders to Literacy instructional manual (O'Connor et al. 2005).

High support scaffolding strategies are those that help children to successfully participate in activities that may be difficult for them. The high support strategies include the eliciting strategy, the reducing choices strategy, and the co-participating strategy. Low support strategies are those that help children to continue to successfully participate in activities that may be easy for them by introducing new knowledge and skills. Low support strategies include the generalizing strategy, the reasoning strategy, and the predicting strategy. For definitions and examples of high and low support strategies used for this study, see the Appendix.

\section{Measures}

For the present study, we examined teachers' use of six scaffolding strategies within a single whole class read aloud session. A read aloud session was collected and analyzed for each of the five teachers enrolled in this study in February of the academic year. Each session involved the teacher reading one storybook, The Mitten by Jan Brett (1989), to students in a whole group setting. The sessions were videotaped and subsequently coded in a laboratory setting to document teachers' use of each of the six scaffolding strategies using the definitions previously provided. During coding, trained scorers identified each occurrence for each strategy use, and these were summed for each read aloud observation. To assure the reliability of the coding procedures, point-by-point agreement was calculated for two of the five sessions ( $40 \%$ of the corpus) by two scorers 
working independently; actual agreement was $85 \%$ and $86 \%$ for the two sessions, indicating that the coding scheme could be reliably applied. Any disagreements were resolved through conferencing to arrive at final scores for each session.

Additionally, teachers completed questionnaires regarding their reported use of scaffolding strategies. Teachers completed a questionnaire in January of the school year to gather information on teachers' perceptions of their use of scaffolding during their read alouds. The questionnaire consisted of seven items, which asked respondents to: (a) indicate whether or not they utilized each of six specific scaffolding strategies and (b) to indicate whether they tended to use high or low support scaffolding strategies most often.

\section{Results}

The first aim of the study was to determine the extent to which preschool teachers used six specific types of scaffolding strategies in their classrooms. To address this aim, we analyzed and coded read aloud sessions for amount and type of scaffolding strategy used by five teachers. Results showed that teachers used a total of 138 scaffolding strategies, for an average of 28 strategies per teacher (range 15-42). As shown in Table 1, the strategies were not evenly distributed across the low and high support categories. That is, the majority of strategies used by teachers (96\%) were low support scaffolding strategies $(n=138)$; teachers made an average of 27 low support scaffolding strategies per read aloud session. Of the low support strategies, $45 \%$ involved generalizing, $43 \%$ involved reasoning, and $12 \%$ involved predicting.

Interestingly, teachers employed very little use of high support scaffolding strategies (4\%); in fact, teachers used an average of one high support scaffolding strategy per read aloud session. Of the high support strategies that were used, most involved co-participating, one involved reducing choices, and none involved eliciting (see Table 1). To

Table 1 Descriptive statistics for low and high support scaffolding strategies used by preschool teachers during read alouds

\begin{tabular}{lrrrr}
\hline & $N$ & Minimum & Maximum & Mean \\
\hline Low support strategies & 136 & 15 & 40 & 26.0 \\
Generalizing & 61 & 0 & 28 & 12.2 \\
Reasoning & 58 & 6 & 15 & 11.6 \\
Predicting & 17 & 2 & 5 & 3.4 \\
High support strategies & 5 & 0 & 2 & 1.0 \\
Co-participating & 4 & 0 & 2 & 0.8 \\
Reducing choices & 1 & 0 & 1 & 0.2 \\
Eliciting & 0 & 0 & 0 & 0 \\
\hline
\end{tabular}

further assess the difference between the amount of low and high scaffolding strategies used by teachers, we performed a paired samples $t$-test. The difference between the two means was statistically significant, $t(4)=4.54$, $p=.011$ indicating that teachers used significantly more high support scaffolding strategies than low support strategies.

The second aim of this study was to determine the extent to which teachers' self-report of scaffolding use related to their observed use. To address this aim, we analyzed teacher responses to a questionnaire regarding their rate of use for the six specific scaffolding strategies. Teacher questionnaire analysis showed that the majority of teachers reported that they used the low support scaffolding strategies in their recent whole group read aloud interactions: $60 \%$ of teachers reported that they used generalizing, $100 \%$ reported that they used reasoning, and $100 \%$ reported that they used predicting. In terms of high support strategies, results showed that teachers reported that they utilized these types of strategies frequently as well: $80 \%$ reported that they utilized co-participating, $60 \%$ reported that they utilized reducing choices, and $40 \%$ reported that they utilized eliciting. When asked to categorize whether or not they used more high or low support strategies during read alouds, questionnaire data indicated that $80 \%$ of teachers felt that they used high and low support strategies about the same amount. However, $20 \%$ of teachers felt they utilized high support strategies more frequently.

\section{Discussion}

The present study is contextualized within a larger literature that has shown that young children's participation in read aloud experiences within the preschool classroom is important in order to support their language and literacy development (Price et al. 2009; Justice and Ezell 2002; van Kleeck et al. 2008). Children within preschool classrooms are considerably diverse with respect to their language and literacy skills and competencies (Cabell et al. 2009; Justice and Ezell 2001), and teachers may need to employ differentiated scaffolding strategies in order to meet the needs of heterogeneous groups of children so that they benefit from participation in read alouds. For instance, teacher use of high support strategies, such as reducing choices and coparticipating, may be particularly important for fostering the skills of children who participate in tasks that they find very difficult. The results of this study provide a view as to what types of strategies preschool teachers are using in their classrooms during read aloud sessions. Results from our study revealed that teachers utilized varying types of scaffolding strategies disproportionately during read aloud interactions, and that their predominant strategies were best 
characterized as low support. Additionally, results showed that teachers' perception of their use of scaffolding differed substantially from observed use. We discuss these findings in turn.

Our first finding showed that teachers in our study utilized low support strategies much more frequently than high support strategies during read aloud interactions. In fact, the low support strategies of reducing choices, coparticipating, and eliciting occurred at very low rates, averaging only one use per teacher studies. Therefore, this finding suggests that the teachers in this study are making little use of those strategies that provide extra support for children who are having difficulty with tasks. This finding was somewhat surprising, given that the teachers in this study were teaching within Head Start classrooms in which the children came primarily from low-income backgrounds. The teachers' limited use of high support strategies suggested that at least some children participating in the whole group read aloud sessions may not have received the types of scaffolding that might have most benefited them. In other words, those children who may find tasks difficult during read alouds and require more support during these types of activities may not be exposed to scaffolding strategies that are appropriate for their level of need.

Our second finding suggested that teacher perceptions of their use of scaffolding strategies is miscalibrated. The majority of teachers reported that they used equal amounts of high and low support scaffolding strategies, which was discordant with actual findings. Previous research has resulted in similar findings regarding teachers' difficulty with accurately calibrating their knowledge of reading related subject matter (Cunningham et al. 2004). Our finding suggests a need for greater professional development to increase teacher awareness of how they can use scaffolding, particularly during whole group read alouds to support a variety of language and literacy goals.

\section{Limitations}

The study had several limitations that warrant mention. First, the results of this study may have only limited external validity (generalizability), given the small sample size of only five teachers. Therefore, the degree to which findings can be applied to other contexts and settings with other groups may be questioned. Second, the fact that teachers were observed only once while reading aloud also limits our conclusions. Future studies that collect a more comprehensive representation of observations would help to support our findings. Additionally, the conclusions in our study were derived from observations that were of descriptive nature only. Therefore, we were unable to make any causal arguments from the observations. Finally, children's roles in the read-aloud interactions were not investigated. Analyses of children's responses to scaffolding would deepen our understanding of the benefits of scaffolding in preschool classrooms.

\section{Conclusion}

In conclusion, both theory and research suggest that teacher use of specific scaffolding strategies may have a positive impact on young children's learning, particularly as applied within the whole group read aloud. This study examined preschool teachers' use of six specific strategies, finding that teachers largely relied upon low support strategies with little use of high support strategies. This finding suggests that teachers may not be differentiating their strategy use to the extent needed for all children to benefit from read aloud interactions. Results also showed that teachers' perceptions of their use of scaffolding differs from observed use, in that teachers believed they used high support strategies when, in fact, they seldom did. Findings may have implications for professional development, in that preschool teachers may benefit from educational opportunities designed to increase their skills in differentiating instruction.

Acknowledgments This research was supported by Grant R30SA080459 from the U.S. Department of Education, Institute of Education Sciences. We would like to thank the program administrators, research assistants, teachers, and children who made this study possible.

\section{Appendix}

Appendix Description and examples for six scaffolding strategies

\begin{tabular}{|c|c|c|}
\hline & Descriptive & Example \\
\hline \multicolumn{3}{|c|}{ Low support strategies } \\
\hline Generalizing & $\begin{array}{l}\text { Prompts children to } \\
\text { extend the lesson } \\
\text { content beyond the } \\
\text { lesson itself-to past or } \\
\text { future personal } \\
\text { experiences }\end{array}$ & $\begin{array}{l}\text { Tell me about a time you } \\
\text { felt really nervous. } \\
\text { Where were you and } \\
\text { what was happening? }\end{array}$ \\
\hline Reasoning & $\begin{array}{l}\text { Prompts children to } \\
\text { explain why something } \\
\text { happened or will } \\
\text { happen, or to explain } \\
\text { why something is the } \\
\text { way it is }\end{array}$ & $\begin{array}{l}\text { Some animals have big } \\
\text { jaws and other animals } \\
\text { have small jaws. Angel, } \\
\text { can you tell me why? }\end{array}$ \\
\hline Predicting & $\begin{array}{l}\text { Prompts children to } \\
\text { describe what might } \\
\text { happen next or to } \\
\text { hypothesize the } \\
\text { outcome of an event/ } \\
\text { activity }\end{array}$ & $\begin{array}{l}\text { What do you think they } \\
\text { will find? }\end{array}$ \\
\hline
\end{tabular}


Appendix continued

\begin{tabular}{|c|c|c|}
\hline & Descriptive & Example \\
\hline \multicolumn{3}{|c|}{ High support strategies } \\
\hline $\begin{array}{l}\text { Co- } \\
\text { participating }\end{array}$ & $\begin{array}{l}\text { Prompts children to } \\
\text { produce a correct answer } \\
\text { to a task through their } \\
\text { completion of the task } \\
\text { with another person- } \\
\text { the teacher or a peer }\end{array}$ & $\begin{array}{l}\text { Jose, bat and cat rhyme. } \\
\text { Let's say it together: } \\
\text { bat, cat }\end{array}$ \\
\hline $\begin{array}{l}\text { Reducing } \\
\text { choices }\end{array}$ & $\begin{array}{l}\text { Prompts children to } \\
\text { complete a task by } \\
\text { reducing the number of } \\
\text { choices of correct } \\
\text { answers }\end{array}$ & $\begin{array}{l}\text { What is this part of the } \\
\text { animal called? Is it the } \\
\text { teeth or the jaw? }\end{array}$ \\
\hline Eliciting & $\begin{array}{l}\text { Prompts children to } \\
\text { produce a correct answer } \\
\text { to a task by providing an } \\
\text { exact model of the ideal } \\
\text { response }\end{array}$ & $\begin{array}{l}\text { What does this word } \\
\text { say? This word says } \\
\text { Danger. Rashaun, say } \\
\text { "Danger" }\end{array}$ \\
\hline
\end{tabular}

\section{References}

Baumann, J. F., \& Bergeron, B. S. (1993). Story map instruction using children's literature: Effects on first graders' comprehension of central narrative elements. Journal of Reading Behavior, 25, 407-437.

Berk, L. E., \& Winsler, A. (1999). Scaffolding children's learning: Vygotsky and early childhood education. Washington, DC: National Association for the Education of Young Children.

Bodrova, E., \& Leong, D. J. (2007). Tools of the mind: The Vygotskian approach to early childhood education. Upper Saddle River, NJ: Pearson Education, Inc.

Bowey, J. A. (1995). Socioeconomic status differences in preschool phonological sensitivity and first-grade reading achievement. Journal of Educational Psychology, 87(3), 476-487.

Brett, J. (1989). The Mitten. New York, NY: Scholastic.

Bus, A. G. (2001). Joint caregiver-child storybook reading: A route to literacy development. In S. B. Neuman \& D. K. Dickinson (Eds.), Handbook of early literacy research (Vol. 1, pp. 179191). New York: The Guilford Press.

Cabell, S. Q., Justice, L. M., Konold, T. R., \& McGinty, A. S. (2009). Profiles of emergent literacy skills among preschool children who are at risk for academic difficulties. Manuscript submitted for publication.

Cazden, C. B. (1988). Classroom discourse: The language of teaching and learning. Portsmouth, NH: Heinemann.

Christian, K., Morrison, F. J., \& Bryant, F. B. (1998). Predicting kindergarten academic skills: Interactions among child care, maternal education, and family literacy environments. Early Childhood Research Quarterly, 13(3), 501-521.

Cunningham, A. E., Perry, K. E., Stanovich, K. E., \& Stanovich, P. J. (2004). Disciplinary knowledge of K-3 teachers and their knowledge calibration in the domain of early literacy. Annals of Dyslexia, 54(1), 139-167.

Dickinson, D. K., De Temple, J. M., Hirschler, J. A., \& Smith, M. W. (1992). Book reading with preschoolers: Coconstruction of text at home and at school. Early Childhood Research Quarterly, 7, 323-346.

Dickinson, D. K., \& Smith, M. W. (1994). Long-term effects of preschool teachers' book readings on low-income children's vocabulary and story comprehension. Reading Research Quarterly, 29, 104-122.

Dickinson, D. K., \& Tabors, P. O. (2001). Beginning literacy with language. Baltimore, MD: Paul H. Brookes Publishing Co.

Dodd, B., \& Carr, A. (2003). Young children's letter-sound knowledge. Language, Speech and Hearing Services in Schools, 34(2), 128-137.

Heath, S. (1983). Ways with words: Language, life, and work in communities and classrooms. Cambridge, UK: Cambridge University Press.

Henderson, S. D., Many, J. E., Wellborn, H. P., \& Ward, J. (2002). How scaffolding nurtures the development of young children's literacy repertoire: Insiders' and outsiders' collaborative understandings. Reading Research and Instruction, 41(4), 309-330.

Huttenlocher, J., Vasilyeva, M., Cymerman, E., \& Levine, S. (2002). Language input and child syntax. Cognitive Psychology, 45(3), 337-374.

Justice, L. M., \& Ezell, H. K. (2001). Word and print awareness in 4year-old children. Child Language Teaching \& Therapy, 17(3), 207.

Justice, L. M., \& Ezell, H. M. (2002). Use of storybook reading to increase print awareness in at-risk children. American Journal of Speech-Language Pathology, 11, 17-29.

Justice, L. M., Mashburn, A. J., Hamre, B. K., \& Pianta, R. C. (2008). Quality of language and literacy instruction in preschool classrooms serving at-risk pupils. Early Childhood Research Quarterly, 23(1), 51-68.

Karweit, N. (1989). The effects of a story-reading program on the vocabulary and story comprehension skills of disadvantaged prekindergarten and kindergarten students. Early Education and Development, 1, 105-114.

Lynch, J., \& van den Broek, P. (2007). Understanding the glue of narrative structure: Children's on- and off-line inferences about characters' goals. Cognitive Development, 22, 323-340.

Mashburn, A. J., Justice, L. M., Downer, J. T., \& Pianta, R. C. (2009). Peer effects on children's language achievement during prekindergarten. Child Development, 80, 686-702.

Morrow, L. M. (1988). Young children's responses to one-to-one story readings in school settings. Reading Research Quarterly, 23, 89-107.

National Center for Education Statistics. (2008). The condition of education 2007: Indicator 2 Enrollment in early childhood education programs. http://nces.ed/gov. Retrieved 10 January 2008.

National Early Literacy Panel. (2008). Developing early literacy. Washington, DC: National Institute for Literacy.

Neuman, S. (1996). Children engaging in storybook reading: The influence of access to print resources, opportunity and parental interaction. Early Childhood Research Quarterly, 11, 495-513.

Neuman, S. B., \& Roskos, K. (2005). The state of pre-kindergarten standards. Early Childhood Research Quarterly, 20, 125-145.

Norris, J. A., \& Hoffman, P. R. (1990). Language intervention within naturalistic environments. Language, Speech, and Hearing Services in Schools, 21(2), 72-84.

O’Connor, R. E., Notari-Syverson, A., \& Vadasy, P. F. (2005). Ladders to literacy. Baltimore, MD: Paul H. Brookes Publishing.

Ohio Department of Education. (2008). Early learning content standards. http://www.ode.state.oh.us/GD. Retrieved 14 November 2008.

Olswang, L. B., Bain, B. A., \& Johnson, G. A. (1992). Using dynamic assessment with children with language disorders. In S. F. Warren \& J. E. Reichle (Eds.), Causes and effects in communication and language intervention (pp. 187-215). Baltimore, MD: Paul H. Brookes.

Pellegrini, A. D., \& Galda, L. (1991). Longitudinal relations among preschoolers' symbolic play, metalinguistic verbs and emergent 
literacy. In J. Christie (Ed.), Play and early literacy development (pp. 47-68). Albany: SUNY Press.

Pellegrini, A. D., \& Galda, L. (2003). Joint reading as a context: Explicating the way context is created by participants. In A. van Kleeck, A. A. Stahl, \& E. B. Bauer (Eds.), On reading books to children: Parents and teachers (pp. 321-325). Mahwah, NJ: Lawrence Erlbaum.

Pellegrini, A. D., Perlmutter, J., Galda, L., \& Brody, G. (1990). Joint book reading between Black Head Start children and their mothers. Child Development, 61, 443-453.

Pence, K. L., Justice, L. M., \& Wiggins, A. K. (2008). Preschool teachers' fidelity in implementing a comprehensive languagerich curriculum. Language, Speech, and Hearing Services in Schools, 39(3), 329.

Pressley, M., Hogan, K., Wharton-McDonald, R., Mistretta, J., \& Ettenberger, S. (1996). The challenges of instructional scaffolding: The challenges of instruction that supports student thinking. Special Issue: Constructivism and Students with Special Needs: Issues in the Classroom, 11(3), 138-146.

Price, L. H., van Kleeck, A., \& Huberty, C. J. (2009). Talk during book sharing between parents and preschool children: A comparison between storybook and expository book conditions. Reading Research Quarterly, 44, 171-194.

Roberts, R. N., \& Barnes, M. L. (1992). "Let momma show you how": Maternal-child interactions and their effects on children's cognitive performance. Journal of Applied Developmental Psychology, $13,363-376$.

Rodgers, E. M. (2005). Interactions that scaffold reading performance. Journal of Literacy Research, 36, 501-532.

Rogoff, B. (1990). Apprenticeship in thinking: Cognitive development in social context. New York: Oxford University Press.

Scarborough, H. S., \& Dobrich, W. (1994). On the efficacy of reading to preschoolers. Developmental Review, 14, 245-302.

Senechal, M. (1997). The differential effect of storybook reading on preschoolers' acquisition of expressive and receptive vocabulary. Journal of Child Language, 24, 123-138.

Senechal, M., \& Cornell, E. H. (1993). Vocabulary acquisition through shared reading experiences. Reading Research Quarterly, 28, 360-374.

Sénéchal, M., Lefevre, J. A., Thomas, E., \& Daley, K. (1998). Differential effects of home literacy experiences on the development of oral and written language. Reading Research Quarterly, 33(1), 96-116.
Snow, C. E., Burns, M. S., \& Griffin, P. (1998). Preventing reading difficulties in young children. Washington, DC: National Academy Press.

Sulzby, E., \& Teale, W. (1996). Emergent literacy. In R. Barr, M. L. Kamil, P. B. Mosenthal, \& P. D. Pearson (Eds.), Handbook of reading research (Vol. 2, pp. 727-757). Mahwah, NJ: Lawrence Erlbaum.

Teale, W. H. (2003). Reading aloud to young children as a classroom instructional activity: Insights from research and practice. In A. van Kleeck, A. A. Stahl, \& E. B. Bauer (Eds.), On reading books to children: Parents and teachers (pp. 114-139). Mahwah, NJ: Lawrence Erlbaum.

Tharp, R. G., \& Gallimore, R. (1988). Rousing minds to life: Teaching, learning, and schooling in social context. New York: Cambridge University Press.

United States Department of Health \& Human Services, Administration for Children \& Families, Office of Head Start (2000). Head Start child outcomes framework. http://www.hsnrc.org. Retrieved 8 January 2008.

van Kleeck, A. (2003). Research on book sharing: Another critical look. In A. van Kleeck, A. A. Stahl, \& E. B. Bauer (Eds.), On reading books to children: Parents and teachers (pp. 271-320). Mahwah, NJ: Lawrence Erlbaum.

van Kleeck, A., Vander Woude, J., \& Hammett, L. (2006). Fostering literal and inferential language skills in Head Start preschoolers with language impairment using scripted book-sharing discussions. American Journal of Speech-Language Pathology, 15(1), $85-95$.

Vygotsky, L. S. (1978). Mind in society: The development of higher psychological processes. Cambridge, MA: Harvard University Press.

Walsh, B. A., \& Blewitt, P. (2006). The effect of questioning style during storybook reading on novel vocabulary acquisition of preschoolers. Early Childhood Education Journal, 33, 273-278.

Whitehurst, G. J., \& Lonigan, C. J. (1998). Child development and emergent literacy. Child Development, 69, 848-872.

Wood, D., Bruner, J. S., \& Ross, G. (1976). The role of tutoring in problem solving. Journal of Child Psychology and Psychiatry, 17(2), 89-100. 